The fournal publishes research and reviews on all aspects of the African past. Contributors should keep in mind the general readership for whom they are writing and relate their findings specifically to relevant secondary literature.

Contributions may be sent to any of the Editors listed on the inside cover; they should be addressed to them at their Departments of History.

Authors may submit contributions in either English or French. They should not exceed about 6000 words (excluding notes), except with the prior approval of the Editors. Where appropriate, carefully drawn maps, photographs, and other illustrations should accompany the text. A summary of the contents of the article, not exceeding about 300 words, should be attached on a separate sheet.

Contributors should seek clarity, brevity, and simplicity of expression and avoid long sentences and unduly lengthy or short paragraphs. They should closely observe the conventions set out below ('Format and Style').

Typescripts or print-outs must be checked personally before despatch, to remove accidental errors.

Page proofs will be sent to each contributor, if necessary by air mail. Corrections must be kept to a minimum: they should not include new material. Contributors should be prepared to return corrected proofs promptly. Authors of articles and review articles receive 25 free offprints and may purchase additional copies, provided that they order before publication on the form sent out with proofs.

\title{
Format and Style
}

Articles should be submitted in two copies. They should be typed in double-spacing throughout. Lines beginning new paragraphs should be indented. Ample margins (at least one inch left and right, one and one-half inches top and bottom) must be left, and all pages should be numbered.

Spelling (in English) may follow either British or American convention but must be consistent. African words and names should conform to the orthography of the International African Institute. In referring to people, Bantu prefixes should normally be omitted: thus 'Luganda', 'Buganda', but 'a Ganda', 'the Ganda'.

Quotations of more than forty words or so should begin on a new line, indented from the left-hand margin.

Italics should be used only for the names of publications and for words in languages other than English. Foreign words should be used only when necessary, and then only with a translation in parentheses.

Figures should be used for units of measurement, percentages (to be shown in the form ' 7 per cent', not ' $7 \%$ '), and any number which includes a decimal point. Spell out other numbers up to ten and multiples of ten up to one hundred ('seven', 'twenty', but ' 25 ', ' 127 ', and ' 10,000 '). Cite dates in the form ' 12 February 1968' (or 'Feb.' in sourcereferences). Express sequences in the briefest form possible (' $68-9$ ', but ' 19 I I-I I2', ' $1849-50$ ').

Notes should be numbered consecutively throughout the article and typed doublespaced, separately from the text. Citations of references should be made only in the notes and not in the text, and there should be no separate bibliography. First references should be given in full, thus: S. Johnson, The History of the Yorubas (Lagos, $192 \mathrm{I}$ ); E. W. Smith, 'Sebetwane and the Makololo', African Studies, xv (1956), 49-74. All subsequent references should be given in abbreviated form, thus: Johnson, History, 43; Smith, 'Sebetwane', 65 except that ibid. should be used to refer to an immediately preceding citation of a title. Loc. cit. and op. cit. should not be used. Use abbreviations of periodical titles where these are reasonably familiar (e.g. $\mathcal{F}$. Afr. Hist.). Archival citations should be as brief as is consistent with clarity. The identity and location of each archive must be fully spelled out where it is first cited.

Maps should be prepared where the topography is important for an understanding of the text. Maps should if possible be camera-ready and show all relevant information, but only such information as is mentioned in the text. Photographs should specifically enhance the 


\section{The Journal of African History}

VOLUME $31 \cdot 1990$ NUMBER 2

CONTENTS

I Sickle Cell Anaemia, Genetic Variations and the Slave Trade to the United States

WALTER A. SCHROEDER California Institute of Technology, EDwin S. Munger California Institute of Technology and DarLeEn R. Powars University of Southern California

II Mturya: Famine in Central Tanzania, 1917-20 Gregory MadDox Texas Southern University

Conservatives and Revolutionaries in Muslim Societies

III Generational Conflict in the Umarian Movement after the Yihäd: Perspectives from the Futanke Grain Trade at Medine

JohN H. Hanson West Chester University

IV Revolutionary Mahdism and Resistance to Colonial Rule in the Sokoto Caliphate, $1905-6$

Paul E. Lovejoy York University, Ontario and J S. Hogendorn Colby College, Maine

\section{Text-in-Context}

V 'The Chronicle of the Succession': an Important Document for the Umarian State David RoBInson Michigan State University

\section{Politics in the Late Colonial Period}

VI The Youngmen and the Porcupine: Class,

Nationalism and Asante's Struggle for Selfdetermination, 1954-57

Jgan Marie Aluman University of Missomi

VII The 'Igbo Scare' in the British Cameroons, c. $1945-61$

Victor Bong AmaAzer Ecole Normale Supérieure, Bambili, Mezam, Cameroun

VIII Alcohol, Racial Segregation and Popular Politics in Northern Rhodesia

Charles Ambler University of Texas at El Paso 